\title{
WOOD COLORIMETRY OF NATIVE SPECIES OF MYRTACEAE FROM A ARAUCARIA FOREST
}

\author{
Helena Cristina Vieira ${ }^{1 *}$, Eliane Lopes da Silva ${ }^{1}$, Joielan Xipaia dos Santos ${ }^{1}$, Graciela Inés Bolzon de Muñiz ${ }^{1}$, \\ Simone Ribeiro Morrone ${ }^{1}$, Silvana Nisgoski ${ }^{1}$ \\ ${ }^{1}$ Federal University of Paraná - Curitiba, PR, Brazil. \\ lenacristin@gmail.com*, eliane0103@gmail.com, joilan87xipaya@gmail.com, graciela.ufpr@gmail.com, morroni@ufpr.br, \\ silvana.ufpr@gmail.com.
}

Recebido para publicação: 05/03/2018 - Aceito para publicação: 29/05/2018

\begin{abstract}
Colorimetric parameters have potential to differentiate tree species through their wood type. Therefore, this can be used to aid the inspection of illegal trade. Thus, considering the need to identify species with precision and speed, this study aimed to explore the potential of these parameters in order to characterize wood of some species of native Myrtaceae from the Araucaria Forest: Campomanesia xanthocarpa Berg., Eugenia pyriformis Cambess., Myrcia retorta Cambess., and Plinia Peruviana (Poir.) Govaert. Twelve trees were collected randomly - three per species - for the removal of a disc at diameter at breast height (DBH). We took samples from three regions of the disc (next to the bark, intermediate and next to the pith) and analyzed them in three anatomical sections (transversal, radial and tangential) by the system CIE L*a*b* using a bench colorimeter. We analyzed the data based on the following criteria: test of means in order to differentiate species, quantitative factor analysis (considering the region of the disc and the anatomical section as factors), and principal components analysis (PCA). Then, we used the original spectrum and the values of parameters $\mathrm{L}^{*}, \mathrm{a}^{*}$ and $\mathrm{b}^{*}$ in order to verify the distribution of the species. The analysis determined that the species present different values for the colorimetric parameters. In addition, the factors region of the disc and anatomical section have specific influence for each species. Finally, the PCA indicated that only E. pyriformis differs from the others.

Keywords: Wood identification, trade, visible spectroscopy.
\end{abstract}

\section{Resumo}

Colorimetria da madeira de espécies de Myrtaceae nativas da Floresta Ombrófila Mista. Os parâmetros colorimétricos possuem potencial para diferenciar espécies arbóreas por meio de sua madeira e, com isso, podem ser utilizados como subsídio para a fiscalização do comércio ilegal. Dessa forma, considerando a necessidade de identificar espécies com precisão e rapidez, o objetivo deste trabalho foi explorar o potencial desses parâmetros para caracterizar a madeira de algumas espécies de Myrtaceae nativas da Floresta Ombrófila Mista: Campomanesia xanthocarpa Berg, Eugenia pyriformis Cambess., Myrcia retorta Cambess. e Plinia peruviana (Poir.) Govaert. Doze indivíduos foram coletados aleatoriamente, três por espécie, para a retirada de um disco no diâmetro à altura do peito (DAP). Amostras foram obtidas em três regiões do disco (próxima à casca, intermediária e próxima à medula) e foram analisadas nos três planos anatômicos de corte (transversal, radial e tangencial) pelo sistema CIE L*a*b*, utilizando um colorímetro de bancada. Os dados foram analisados com base nos seguintes critérios: teste de médias para diferenciar as espécies, análise fatorial quantitativa (considerando a posição no tronco e o plano anatômico de corte como fatores) e análise dos componentes principais (PCA), que utilizou o espectro original e os valores dos parâmetros L*, a* e b* para verificar a distribuição das espécies. Constatou-se que as espécies apresentam valores distintos para os parâmetros colorimétricos e que os fatores posição no tronco e plano anatômico de corte apresentam influência específica para cada espécie. Por fim, a PCA indicou que somente a espécie E. pyriformis diferencia-se das demais.

Palavras-chave: Identificação de madeiras, comércio, espectroscopia no visível.

\section{INTRODUCTION}

The Araucaria Forest is known for its great variability and unique aspects. In the state of Santa Catarina (Brazil), there are 925 species of 439 genera and 116 families of spermatophytes, among which the Myrtaceae family stands out as the second largest family in number of representatives, with approximately 88 species (GASPER et al., 2013). However, despite the high diversity, Souza and Lorenzi (2008) claim that the Myrtaceae family imposes great difficulty for the species differentiation by having a very homogeneous taxonomic structure. This structure specifies the criteria of separation among the large groups, e.g. the type of embryo. However, the correct identification of species used in the timber industry is essential, since different species are

FLORESTA, Curitiba, PR, v. 49, n. 2, p. 353-362, abr/jun 2019.

Vieira. H. C. et.al.

ISSN eletrônico 1982-4688

DOI: $10.5380 /$ rf.v49 i2.58236 
in different states of conservation, according to the Brazilian Official List of Species of Endangered Flora, and some of them are traded illegally (MMA, 2014).

Thus, the need to use alternative characteristics that allow the correct identification of the wood is evident, such as those revealed through colorimetry, DNA and near-infrared spectroscopy (MORI et al., 2005; NUNES et al., 2009; OLIVEIRA et al., 2015). Therefore, the wood color is one of the most important macroscopic aspects for the species differentiation (MORI et al., 2005) and its potential has already been evaluated by several studies (NISGOSKI et al., 2017; CAMARGOS; GONÇALVES, 2001; SILVA et al., 2015, SILVA et al., 2017). Nevertheless, studies on colorimetry are still necessary to identify the particularities of each species based on characteristics such as growth rings, vessels, rays, parenchyma type, extractive content, among others (GARCIA; MORINONIO, 2016).

These characteristics are influenced by several factors, especially the variation among species, among each tree of the same species, and within the same tree (SILVA et al., 2017). In addition, variation may occur according to the anatomical section in which the analysis was performed (ATAYDE et al., 2011; NISHINO et al., 2000). Therefore, in order to minimize interferences in determining wood color, correct and accurate reading of the CIE $\mathrm{L}^{*} \mathrm{a} \mathrm{b}^{*}$ system is indicated, which can be made using colorimeters or spectrophotometers (MORI et al., 2004). Through this system, we can perform readings that detect color changes on the wood surface (BUCHELT; WAGENFÜHR, 2012). Thus, when using the results obtained by this feature in association with different statistical methods, it is possible to define if the samples collected are similar or different to each of the characteristics aforementioned.

Hence, as we consider the need to identify particularities of each species in order to differentiate them through wood, the aim of this study was to characterize the wood color of some species of native Myrtaceae to the Araucaria Forest: Campomanesia xanthocarpa Berg; Eugenia pyriformis Cambess; Myrcia retorta Cambess; Plinia Peruviana (Poir.) Govaert.

\section{MATERIAL AND METHODS}

Trees of four species of Myrtaceae, native to the Araucaria Forest, were collected in an area that was later flooded for the implantation of the São Roque Hydroelectric Power Plant (in the state of Santa Catarina, Brazil). This region encompasses the municipalities of São José do Cerrito, Campos Novos, Brunópolis, Curitibanos, Frei Rogério, and Vargem. Table 1 shows the scientific and popular names of the species and record number of the samples in the Lages Herbarium of the Santa Catarina State University (LUSC). It also shows the diameter at breast height of the trees, geographic coordinates and altitude of the collection site. The acess to material is registered at Conselho de Gestão do Patrimônio Genético (CGEN/SISGEN) under number AF3EDDC.

Table 1. Scientific and popular names of the collected species, record number of samples in the LUSC, diameter at breast height of the trees, geographic coordinates, and altitude of the collection site.

Tabela 1. Nomes científicos e populares das espécies coletadas, número do registro das amostras no herbário LUSC, diâmetro à altura do peito (DAP) das árvores, coordenadas geográficas e altitude do local da coleta.

\begin{tabular}{|c|c|c|c|c|c|}
\hline Species & $\begin{array}{l}\text { Popular } \\
\text { name }\end{array}$ & $\begin{array}{l}\text { Record } \\
\text { number }\end{array}$ & $\begin{array}{l}\text { DBH } \\
(\mathrm{cm})\end{array}$ & Coordinate & $\begin{array}{l}\text { Altitude } \\
\text { (m) }\end{array}$ \\
\hline \multirow{3}{*}{$\begin{array}{c}\text { Campomanesia } \\
\text { xanthocarpa Berg }\end{array}$} & \multirow{3}{*}{ "Guabiroba" } & LUSC 6188 & 39.5 & lat: -27.497031 long: -50.810531 WGS84 & 680 \\
\hline & & LUSC 6189 & 34.0 & lat: -27.483358 long: -50.808750 WGS84 & 730 \\
\hline & & LUSC 6190 & 22.0 & lat: -27.483217 long: -50.808783 WGS84 & 733 \\
\hline \multirow{3}{*}{$\begin{array}{c}\text { Eugenia } \\
\text { pyriformis } \\
\text { Cambess. }\end{array}$} & \multirow{3}{*}{ "Uvaia" } & LUSC 6219 & 18.0 & lat: -27.489200 long: -50.975007 WGS84 & $*$ \\
\hline & & LUSC 6220 & 15.0 & lat: -27.482667 long: -50.811278 WGS84 & 750.9 \\
\hline & & LUSC 6221 & 15.0 & lat: -27.482761 long: -50.811514 WGS84 & 752.7 \\
\hline \multirow{3}{*}{$\begin{array}{l}\text { Myrcia retorta } \\
\text { Cambess. }\end{array}$} & \multirow{3}{*}{$\begin{array}{l}\text { "Guamirim- } \\
\text { ferro" }\end{array}$} & LUSC 6252 & 27.1 & lat: -27.492825 long: -50.812278 WGS84 & 764.7 \\
\hline & & LUSC 6253 & 17.3 & lat: -27.492783 long: -50.812303 WGS84 & 790.6 \\
\hline & & LUSC 6254 & 10.6 & lat: -27.492894 long: -50.812364 WGS84 & 758.4 \\
\hline \multirow{3}{*}{$\begin{array}{l}\text { Plinia peruviana } \\
\text { (Poir.) Govaerts }\end{array}$} & \multirow{3}{*}{ "Jaboticaba" } & LUSC 6324 & 25.8 & lat: -27.497356 long: -50.810294 WGS84 & 713.3 \\
\hline & & LUSC 6325 & 26.0 & lat: -27.493700 long: -50.803347 WGS84 & 622.5 \\
\hline & & LUSC 6326 & 22.7 & lat: -27.493750 long: -50.802928 WGS84 & 708.5 \\
\hline
\end{tabular}


In total, we collected twelve trees - three of each species - randomly chosen in the field, two wood discs from each tree, approximately $5 \mathrm{~cm}$ in thickness and 1.30 meters above ground (diameter at breast height), and botanical material. One of the discs, along with the botanical material, was used for record and storage in the LUSC. We used the remaining 12 discs - one from each tree - in this study (Figure 1).

In order to cover the largest variation of the wood, we took the sample radially to preserve the orientation of the growth rings and correct distribution of the anatomical elements in the three sections of wood (transversal, radial and tangential). Each disc provided at least six opposing wedge-shaped specimens, taken as: two from the region next to the bark, two from the intermediate region and two from the region next to the pith (larger discs had more specimens removed from the intermediate region). The specimens had dimensions of approximately $2 \mathrm{~cm}$ in length, width and thickness and had their surfaces polished with sanding granules 100, with aim of avoiding the influence of the effects of oxidation and saw marks on the results. Finally, they were stored in a controlled environment (temperature $25 \pm 2{ }^{\circ} \mathrm{C}$ and humidity $50 \pm 2 \%$ ) to standardize the moisture content of the samples.

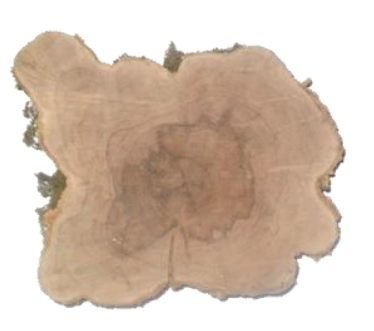

(A)

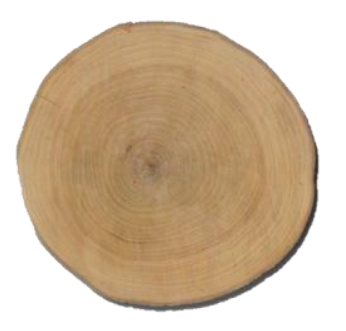

(B)

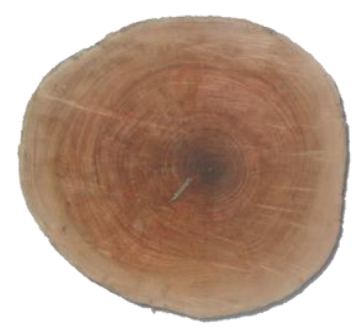

(C)

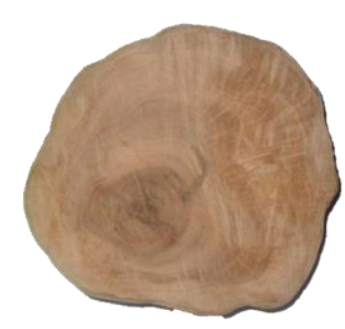

(D)

Figure 1. Cross section of the species discs (A) Campomanesia xanthocarpa Berg, (B) Eugenia pyriformis Cambess., (C) Myrcia retorta Cambess., and (D) Plinia Peruviana (Poir.) Govaert. Bars $=5 \mathrm{~cm}$.

Figura 1. Seção transversal dos discos das espécies (A) Campomanesia xanthocarpa Berg, (B) Eugenia pyriformis Cambess., (C) Myrcia retorta Cambess. e (D) Plinia peruviana (Poir.) Govaert. Barras $=5 \mathrm{~cm}$.

Colorimetric characterization was performed on the basis of the system CIE L*a*b* using Konica Minolta CM-5 spectrophotometer and program Spectra Magic NX, with diffuse xenon lamp, 8 mm sensor aperture diameter, observation of $10^{\circ}$, and illuminant D65. In each test specimen, two readings were taken per anatomical section, which provided the values for $\mathrm{L}^{*}$ (luminosity), $\mathrm{a}^{*}$ (coordinates of the green-red axis), and $\mathrm{b}^{*}$ (coordinates of the blue-yellow axis). The values for $\mathrm{C}$ (saturation) and $\mathrm{h} *$ (ink angle) were calculated according to Equations 1 and 2, respectively.

$$
\begin{aligned}
& C=\left(a^{* 2}+b^{* 2}\right)^{1 / 2} \\
& h^{*}=\tan ^{-1}\left(\frac{b^{*}}{a^{*}}\right)
\end{aligned}
$$

Then, we checked the data normality by the Kolmogorov-Smirnov test and compared the results through the Scott-Knott mean test (at 95\% significance level) using factor analysis, which considered the anatomical section (transversal, radial and tangential) and region of the disc (next to the bark, intermediate and next to the pith). We performed the factor analysis through the software SISVAR (FERREIRA, 2008). For the evaluation of the results, we used the Principal Component Analysis (PCA) in order to understand the behavior of the colorimetric parameters according to the species, anatomical section and region of the disc. The PCA was made by the software The Unscrambler X (version 10.1), based on the algorithm NIPALS and cross-validation.

\section{RESULTS}

Initially, we aimed to perform a general characterization of the samples. Table 2 was built to demonstrate the average behavior of Myrtaceae species in relation to each colorimetric parameter.

Table 2. Mean values of the colorimetric parameters obtained for the wood of the different Myrtaceae species.

FLORESTA, Curitiba, PR, v. 49, n. 2, p. 353-362, abr/jun 2019.

Vieira. H. C. et.al.

ISSN eletrônico 1982-4688

DOI: $10.5380 /$ rf.v49 i2.58236 
Tabela 2. Valores médios dos parâmetros colorimétricos obtidos para a madeira das diferentes espécies de Myrtaceae.

\begin{tabular}{ccccr}
\hline \multirow{2}{*}{ Parameter } & \multicolumn{4}{c}{ Species } \\
\cline { 2 - 5 } & C. xanthocarpa & E. pyriformis & M. retorta & P. peruviana \\
\hline $\mathrm{L}^{*}$ & $55.48 \mathrm{~B}(12.19)$ & $69.75 \mathrm{~A}(4.44)$ & $50.01 \mathrm{C}(13.60)$ & $54.16 \mathrm{~B}(10.16)$ \\
\hline $\mathrm{a}^{*}$ & $7.17 \mathrm{~B}(25.74)$ & 3.69 C $(28.72)$ & $9.87 \mathrm{~A}(16.97)$ & $7.23 \mathrm{~B}(18.49)$ \\
\hline $\mathrm{b}^{*}$ & $15.87 \mathrm{~A}(14.08)$ & $12.76 \mathrm{D}(28.24)$ & $15.16 \mathrm{~B}(16.91)$ & $14.05 \mathrm{C}(11.61)$ \\
\hline $\mathrm{C}$ & $17.49 \mathrm{~A}(13.67)$ & $13.30 \mathrm{C}(27.74)$ & $18.16 \mathrm{~A}(14.32)$ & $15.83 \mathrm{~B}(11.78)$ \\
\hline $\mathrm{h}^{*}$ & $65.70 \mathrm{~B}(7.98)$ & $73.64 \mathrm{~A}(3.99)$ & $56.69 \mathrm{D}(9.33)$ & $62.87 \mathrm{C}(5.81)$ \\
\hline
\end{tabular}

For each parameter, means followed by the same capital letter on line do not differ statistically from one another by the Scott-Knott test (at $95 \%$ level of significance). Coefficient of variation in parentheses.

\section{Factor analysis}

Tables 3 and 4 present the results obtained for the parameters $\mathrm{L}^{*}, \mathrm{a}^{*}$ and $\mathrm{b}^{*}$ and parameters $\mathrm{C}$ and $\mathrm{h}^{*}$, respectively, according to the region of the disc and anatomical section. The aim was to understand the influence of such factors on the behavior of these parameters in the wood of Myrtaceae species.

Table 3. Results obtained for the parameters $L^{*}, a^{*}$ and $b^{*}$ for all Myrtaceae species in the different regions of the disc (next to the bark, intermediate and next to the pith) and in the different anatomical sections (transversal, radial and tangential).

Tabela 3. Resultados obtidos para os parâmetros $\mathrm{L}^{*}, \mathrm{a}^{*} \mathrm{e} \mathrm{b}^{*}$ para todas as espécies de Myrtaceae nas diferentes posições do tronco (próxima à casca, intermediária e próxima à medula) e nos diferentes planos anatômicos de corte (transversal, radial e tangencial).

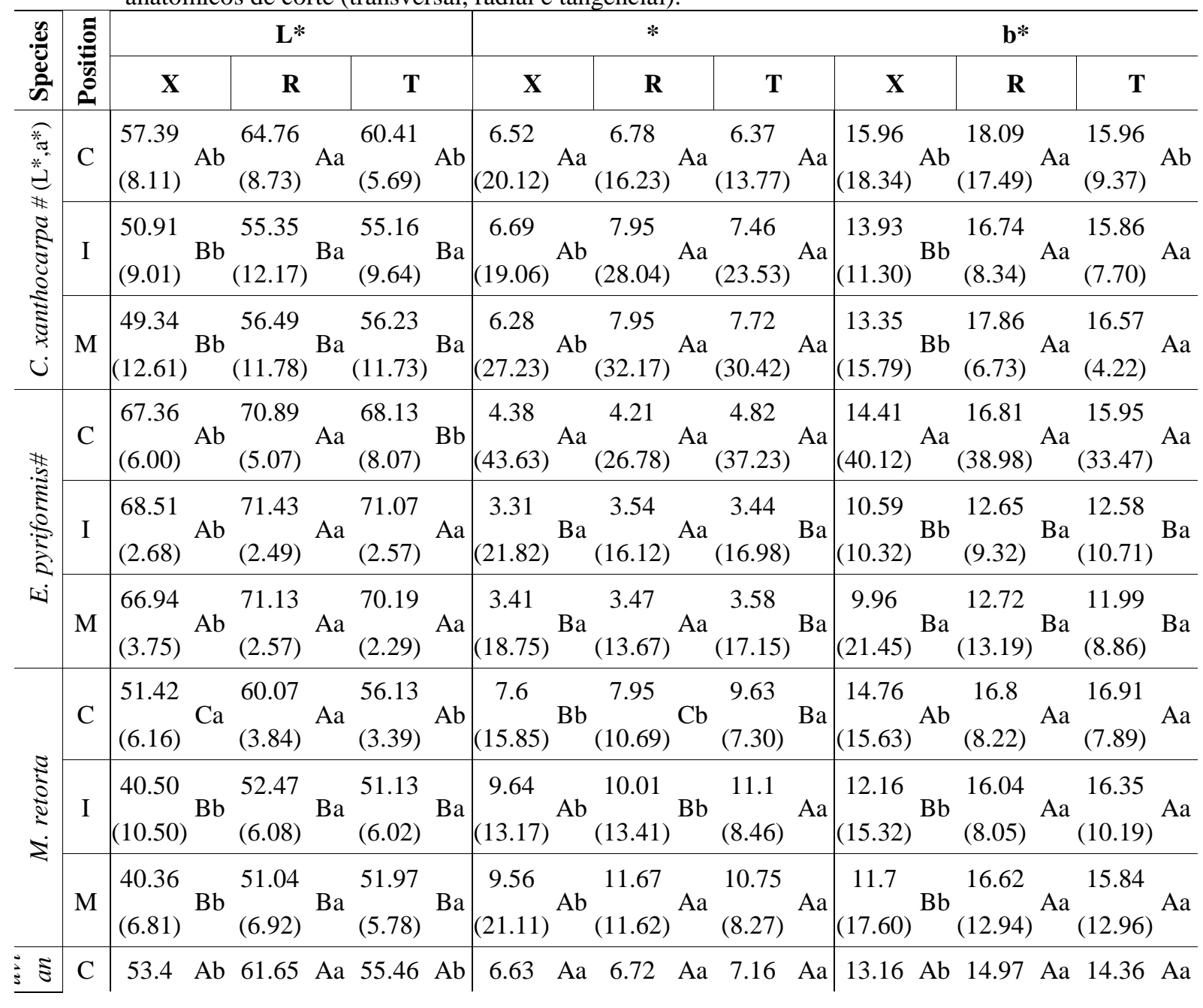




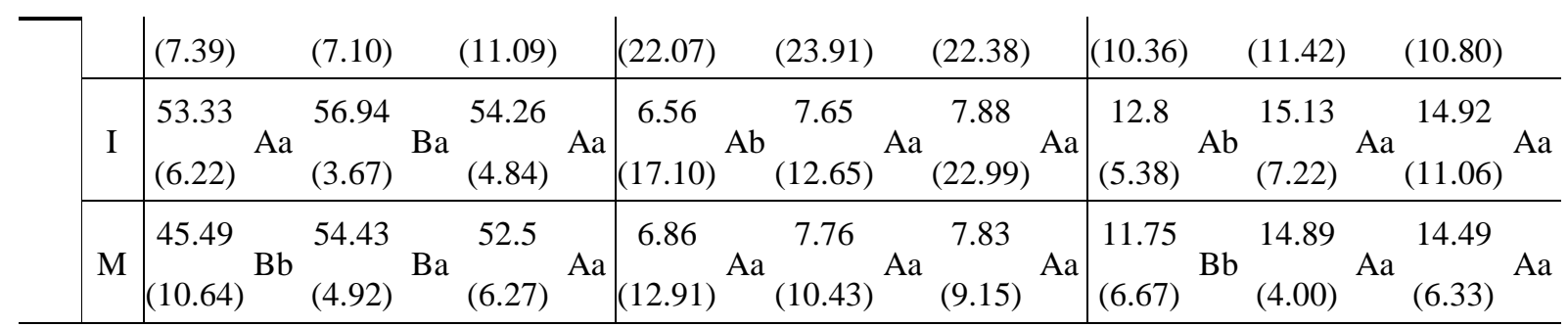

In which: $\mathrm{C}=$ Region next to the bark; $\mathrm{I}=$ Intermediate Region; $\mathrm{M}=$ Region next to the pith; $\mathrm{X}=$ Transversal Section; $\mathrm{R}=\mathrm{Radial}$ Section; and $\mathrm{T}=$ Tangential Section. For each parameter and each species, means followed by the same uppercase letter in the column and lowercase in the line do not differ by the Scott-Knott test (at 95\% level of significance). Coefficient of variation in parentheses. \# Species in which there was no interaction between the factors anatomical section and region of the disc (at $95 \%$ level of significance).

Table 4. Results obtained for the parameters $\mathrm{C}$ and $\mathrm{h}^{*}$ for all species of Myrtaceae in the different regions of the disc (next to the bark, intermediate and next to the pith) and in the different anatomical sections (transversal, radial and tangential).

Tabela 4. Resultados obtidos para os parâmetros $\mathrm{C}$ e h* para todas as espécies de Myrtaceae nas diferentes posições do tronco (próxima à casca, intermediária e próxima à medula) e nos diferentes planos anatômicos de corte (transversal, radial e tangencial).

\begin{tabular}{|c|c|c|c|c|c|c|c|c|c|c|c|c|c|}
\hline \multirow{2}{*}{ 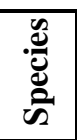 } & \multirow{2}{*}{$\stackrel{0}{0}$} & \multicolumn{6}{|c|}{$\mathrm{C}$} & \multicolumn{6}{|c|}{$\mathbf{h}^{*}$} \\
\hline & & \multicolumn{2}{|c|}{$\mathbf{X}$} & \multicolumn{2}{|l|}{$\mathbf{R}$} & \multicolumn{2}{|l|}{$\mathbf{T}$} & \multicolumn{2}{|l|}{$\mathbf{X}$} & \multicolumn{2}{|c|}{$\mathbf{R}$} & \multicolumn{2}{|l|}{$\mathbf{T}$} \\
\hline \multirow{3}{*}{ 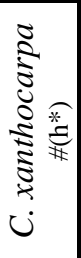 } & $\mathrm{C}$ & $\begin{array}{c}17.3 \\
(16.65) \\
\end{array}$ & $\mathrm{Ab}$ & $\begin{array}{c}19.38 \\
(15.23) \\
\end{array}$ & $\mathrm{Aa}$ & $\begin{array}{l}17.21 \\
(8.06) \\
\end{array}$ & $\mathrm{Ab}$ & $\begin{array}{l}67.49 \\
(6.66) \\
\end{array}$ & $\mathrm{Aa}$ & $\begin{array}{l}69.01 \\
(6.90) \\
\end{array}$ & $\mathrm{Aa}$ & $\begin{array}{l}68.13 \\
(5.09) \\
\end{array}$ & $\mathrm{Aa}$ \\
\hline & I & $\begin{array}{c}15.5 \\
(10.56) \\
\end{array}$ & $\mathrm{Bb}$ & $\begin{array}{c}18.61 \\
(10.38) \\
\end{array}$ & $\mathrm{Aa}$ & $\begin{array}{c}17.6 \\
(8.29) \\
\end{array}$ & $\mathrm{Aa}$ & $\begin{array}{l}64.32 \\
(6.83) \\
\end{array}$ & $\mathrm{Aa}$ & $\begin{array}{l}64.89 \\
(8.24) \\
\end{array}$ & $\mathrm{Aa}$ & $\begin{array}{l}64.93 \\
(7.69) \\
\end{array}$ & $\mathrm{Aa}$ \\
\hline & $\mathrm{M}$ & $\begin{array}{c}14.84 \\
(14.25)\end{array}$ & $\mathrm{Bb}$ & $\begin{array}{l}19.66 \\
(9.09)\end{array}$ & $\mathrm{Aa}$ & $\begin{array}{l}18.38 \\
(7.67)\end{array}$ & $\mathrm{Aa}$ & $\begin{array}{c}64.76 \\
(10.15)\end{array}$ & $\mathrm{Aa}$ & $\begin{array}{l}66.33 \\
(9.52)\end{array}$ & $\mathrm{Aa}$ & $\begin{array}{l}65.39 \\
(9.54)\end{array}$ & $\mathrm{Aa}$ \\
\hline \multirow{3}{*}{ 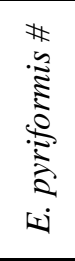 } & $\mathrm{C}$ & $\begin{array}{c}15.09 \\
(39.96) \\
\end{array}$ & $\mathrm{Aa}$ & $\begin{array}{c}17.34 \\
(38.09) \\
\end{array}$ & $\mathrm{Aa}$ & $\begin{array}{r}16.66 \\
(33.73) \\
\end{array}$ & $\mathrm{Aa}$ & $\begin{array}{l}73.02 \\
(5.15) \\
\end{array}$ & $\mathrm{Aa}$ & $\begin{array}{l}75.29 \\
(3.15) \\
\end{array}$ & $\mathrm{Aa}$ & $\begin{array}{l}73.31 \\
(1.69) \\
\end{array}$ & $\mathrm{Aa}$ \\
\hline & I & $\begin{array}{l}11.11 \\
(9.82) \\
\end{array}$ & $\mathrm{Bb}$ & $\begin{array}{l}13.15 \\
(8.85) \\
\end{array}$ & $\mathrm{Ba}$ & $\begin{array}{c}13.06 \\
(10.10) \\
\end{array}$ & $\mathrm{Ba}$ & $\begin{array}{l}72.58 \\
(5.04) \\
\end{array}$ & $\mathrm{Ab}$ & $\begin{array}{l}74.32 \\
(3.41) \\
\end{array}$ & $\mathrm{Aa}$ & $\begin{array}{l}74.63 \\
(3.79) \\
\end{array}$ & $\mathrm{Aa}$ \\
\hline & $\mathrm{M}$ & $\begin{array}{c}10.53 \\
(20.98)\end{array}$ & $\mathrm{Ba}$ & $\begin{array}{c}13.2 \\
(12.45)\end{array}$ & $\mathrm{Ba}$ & $\begin{array}{l}12.52 \\
(9.03) \\
\end{array}$ & $\mathrm{Ba}$ & $\begin{array}{c}70.9 \\
(2.40) \\
\end{array}$ & $\mathrm{Ab}$ & $\begin{array}{c}74.6 \\
(3.31) \\
\end{array}$ & $\mathrm{Aa}$ & $\begin{array}{l}73.42 \\
(2.94) \\
\end{array}$ & $\mathrm{Aa}$ \\
\hline \multirow{3}{*}{$\begin{array}{l}\frac{1}{2} \\
\frac{0}{2} \\
\frac{2}{2} \\
0\end{array}$} & $\mathrm{C}$ & $\begin{array}{c}16.63 \\
(14.65)\end{array}$ & $\mathrm{Ab}$ & $\begin{array}{l}18.58 \\
(8.34)\end{array}$ & $\mathrm{Ba}$ & $\begin{array}{l}19.47 \\
(6.87)\end{array}$ & $\mathrm{Aa}$ & $\begin{array}{l}62.69 \\
(5.14)\end{array}$ & $\mathrm{Ab}$ & $\begin{array}{l}64.71 \\
(2.27)\end{array}$ & $\mathrm{Aa}$ & $\begin{array}{l}60.29 \\
(3.50)\end{array}$ & $\mathrm{Ab}$ \\
\hline & I & $\begin{array}{c}15.56 \\
(12.52) \\
\end{array}$ & $\mathrm{Ab}$ & $\begin{array}{l}18.94 \\
(7.91) \\
\end{array}$ & $\mathrm{Ba}$ & $\begin{array}{c}19.8 \\
(6.99) \\
\end{array}$ & $\mathrm{Aa}$ & $\begin{array}{l}51.43 \\
(8.42) \\
\end{array}$ & $\mathrm{Bc}$ & $\begin{array}{c}58.1 \\
(5.80) \\
\end{array}$ & $\mathrm{Ba}$ & $\begin{array}{l}55.68 \\
(6.73) \\
\end{array}$ & $\mathrm{Bb}$ \\
\hline & $\mathrm{M}$ & $\begin{array}{c}15.13 \\
(18.13)\end{array}$ & $\mathrm{Ab}$ & $\begin{array}{c}20.32 \\
(12.17) \\
\end{array}$ & $\mathrm{Aa}$ & $\begin{array}{c}19.16 \\
(10.89) \\
\end{array}$ & $\mathrm{Aa}$ & $\begin{array}{l}50.89 \\
(6.76) \\
\end{array}$ & $\mathrm{Bb}$ & $\begin{array}{l}54.85 \\
(3.08) \\
\end{array}$ & $\mathrm{Ca}$ & $\begin{array}{l}55.67 \\
(4.38) \\
\end{array}$ & $\mathrm{Ba}$ \\
\hline \multirow{3}{*}{ 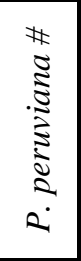 } & $\mathrm{C}$ & $\begin{array}{c}14.76 \\
(11.91) \\
\end{array}$ & $\mathrm{Ab}$ & $\begin{array}{c}16.44 \\
(12.83) \\
\end{array}$ & $\mathrm{Aa}$ & $\begin{array}{c}16.09 \\
(11.69)\end{array}$ & $\mathrm{Aa}$ & $\begin{array}{c}63.5 \\
(6.03) \\
\end{array}$ & $\mathrm{Aa}$ & $\begin{array}{c}66.1 \\
(5.55) \\
\end{array}$ & $\mathrm{Aa}$ & $\begin{array}{l}63.74 \\
(6.92) \\
\end{array}$ & $\mathrm{Aa}$ \\
\hline & I & $\begin{array}{l}14.41 \\
(7.14)\end{array}$ & $\mathrm{Ab}$ & $\begin{array}{l}16.96 \\
(7.94)\end{array}$ & $\mathrm{Aa}$ & $\begin{array}{c}16.92 \\
(12.48)\end{array}$ & $\mathrm{Aa}$ & $\begin{array}{c}63 \\
(5.18)\end{array}$ & $\mathrm{Aa}$ & $\begin{array}{l}63.25 \\
(3.09) \\
\end{array}$ & $\mathrm{Ba}$ & $\begin{array}{l}62.41 \\
(6.84)\end{array}$ & $\mathrm{Aa}$ \\
\hline & $\mathrm{M}$ & $\begin{array}{l}13.62 \\
(6.91)\end{array}$ & $\mathrm{Ab}$ & $\begin{array}{c}16.8 \\
(3.98)\end{array}$ & $\mathrm{Aa}$ & $\begin{array}{l}16.49 \\
(4.85)\end{array}$ & $\mathrm{Aa}$ & $\begin{array}{l}59.77 \\
(4.92)\end{array}$ & $\mathrm{Ba}$ & $\begin{array}{l}62.51 \\
(4.11)\end{array}$ & $\mathrm{Ba}$ & $\begin{array}{l}61.58 \\
(4.77)\end{array}$ & $\mathrm{Aa}$ \\
\hline
\end{tabular}

In which: $\mathrm{C}=$ Region next to the bark; I = Intermediate Region; $\mathrm{M}=$ Region next to the pith; $\mathrm{X}=$ Transversal Section; $\mathrm{R}=\mathrm{Radial}$ Section; and $\mathrm{T}=$ Tangential Section. For each parameter and each species, means followed by the same uppercase letter in the column and lowercase in the line do not differ by the Scott-Knott test (at a level of 95\% significance). Coefficient of variation in parentheses. \# Species in which there was no interaction between the factors anatomical section and region of the disc (at $95 \%$ level of significance).

\section{Principal Component Analysis (PCA)}

Plots (Figure 2) were based on the PCA, which took into account the original spectra and the parameters $\mathrm{L}^{*}, \mathrm{a}^{*}$ and $\mathrm{b}^{*}$ in order to evaluate the behavior of the colorimetric parameters of Myrtaceae species, according to the region of the disc and anatomical section. 

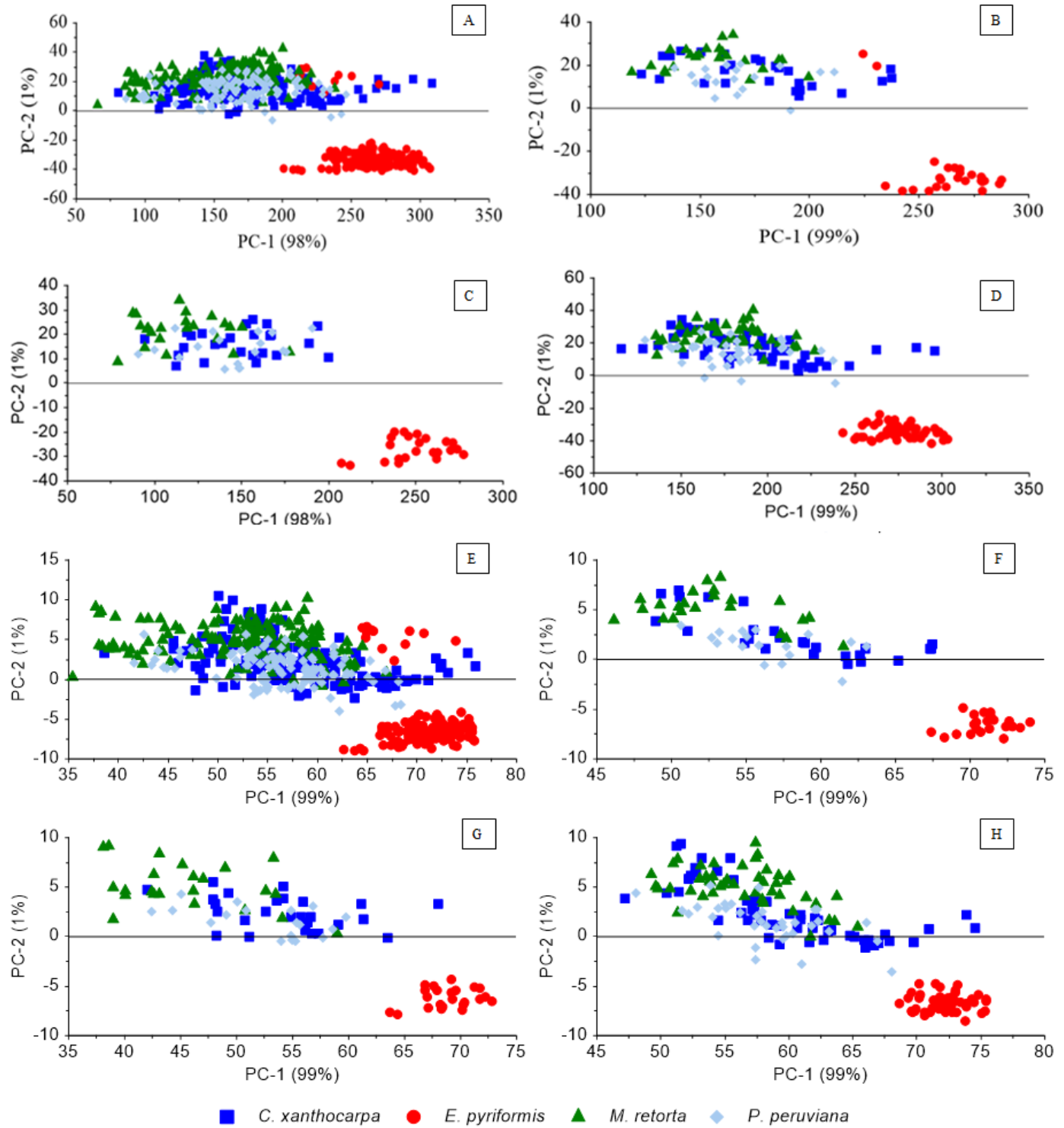

Figure 2. Principal Component Analysis (PCA) for the original spectra: (A) for all data (transversal, radial and tangential sections), (B) for the data means (transversal, radial and tangential sections), (C) considering the means obtained for the transversal section, and (D) considering the means obtained for the radial and tangential sections (longitudinal sections); Principal Component Analysis (PCA) for the parameters $\mathrm{L}^{*}, \mathrm{a}^{*}$ and $\mathrm{b}^{*}$ : (E) for all data (transversal, radial and tangential sections), (F) for the data means (transversal, radial and tangential sections), $(\mathrm{G})$ considering the means obtained for the transversal section, and $(\mathrm{H})$ considering the means obtained for the radial and tangential sections (longitudinal sections).

Figura 2. Análise dos componentes principais para os espectros originais: (A) para todos os dados (planos transversal, radial e tangencial), (B) para as médias dos dados (planos transversal, radial e tangencial), (C) considerando as médias obtidas para o plano transversal e (D) considerando as médias obtidas para os planos radial e tangencial (planos longitudinais); Análise dos componentes principais para os parâmetros $\mathrm{L}^{*}, \mathrm{a}^{*}$ e $\mathrm{b}^{*}$ : (E) para todos os dados (planos transversal, radial e tangencial), (F) para as médias dos dados (planos transversal, radial e tangencial), $(\mathrm{G})$ considerando as médias obtidas para o plano transversal e $(\mathrm{H})$ considerando as médias obtidas para os planos radial e tangencial (planos longitudinais).

\section{Original Spectra Analysis}

Figure 3 shows the reflectance curves of the species analyzed, which are characterized by $360-740$ nanometers $(\mathrm{nm})$. 


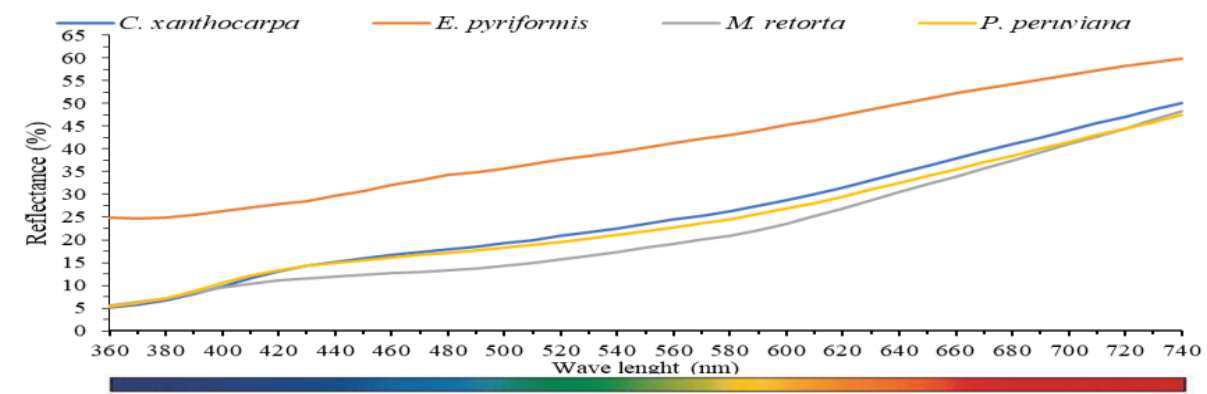

Figure 3. Original Spectra Analysis, based on the reflectance curve of the wood of the species analyzed.

Figura 3. Análise dos espectros originais, com base na curva de refletância da madeira das espécies analisadas.

\section{DISCUSSION}

\section{Colorimetry of wood of Myrtaceae species}

Table 2 presents the mean values of the colorimetric parameters for each species in order to evince the differences among the species. Values varied as: $\mathrm{L}^{*}$ (brightness) between 69.75 and 50.01 ; a* (chromatic coordinate green-red) between 9.87 and 3.69; $b^{*}$ (chromatic coordinate blue-yellow) between 15.87 and 12.76; $\mathrm{C}^{*}$ (color saturation) between 18.16 and 13.30; and $\mathrm{h}$ (ink angle) between 73.64 and 56.69.

When considering the parameter L*, E. pyriformis was highlighted as having the highest mean. According to Camargos and Gonçalez (2001), it is the only one out of the four species that can be classified as having high luminosity $\left(\mathrm{L}^{*}>56\right)$. C. xanthocarpa and $P$. peruviana presented similar values between themselves and intermediate values in comparison to the others, and $M$. retorta had the lowest values observed. Wood with low values of $\mathrm{L}^{*}$ tend to have darkened surfaces (SILVA et al., 2017).

For the parameter $\mathrm{a}^{*}$, the inverse behavior was observed: $M$. retorta presented the highest values, and $E$. pyriformis showed the lowest ones. Barros et al. (2014) claim that species with the highest values for $\mathrm{a}^{*}$ have predominance of red pigment. According to Mori et al. (2004), this behavior can be influenced by the significant correlation between the amount of polyphenols (present in the lignin) and the wood redness.

For the parameter $\mathrm{b}^{*}$, the values decreased C. xanthocarpa, M. retorta, P. peruviana, and E. pyriformis, respectively. The higher the value of $b^{*}$, the greater the amount of yellow pigment present in the wood. Hence, we can consider that the wood of E. pyriformis tends to be less yellowish since it presented the smallest value for this parameter.

The values of $\mathrm{C}$ and $\mathrm{h}^{*}$ were calculated from the values of $\mathrm{a}^{*}$ and $\mathrm{b}^{*}$. Therefore, these values are, for wood, highly influenced by the red and yellow pigments. Silva et al. (2015) also highlight the tendency on the results of $\mathrm{C}$ to follow the behavior of parameter $\mathrm{b}^{*}$. This statement was true for the species studied in this paper: for both parameters, we obtained the highest results for C. xanthocarpa and M. retorta and the smallest ones for E. pyriformis. The parameter $\mathrm{h}^{*}$ confirms the difference in the tonality of the species, since E. pyriformis presented the highest values, and M. retorta presented the lowest ones.

Considering the intervals of the chromatic variables, the wood of the species characterized can be classified into four distinct patterns, according to the table on color identification suggested by Camargos and Gonçalez (2001): pinkish-gray (C. xanthocarpa), grayish-pink (E. pyriformis), dark brown (M. retorta), and olive green (P. peruviana). According to Garcia et al. (2014), the classification of wood in distinct colors is an important factor and may be an indication of the potential of colorimetric parameters for species differentiation. However, Rosu et al. (2010) warn that factors such as weathering and photodegradation can influence the coloring of wood and, in addition, it is necessary to take into account the natural variation in tonality within the trunk and among trees of the same species (CSORDÓS et al., 2014).

\section{Factor analysis}

In relation to the parameter $\mathrm{L}^{*}$ for the factor anatomical section, the radial and tangential sections were in general superior to the transversal section and did not present statistical differences among themselves - a behavior that has already been reported in other studies (VANCLAY et al., 2008; CADEMARTORI et al., 2013). Nevertheless, this tendency was not observed in the samples next to the bark of the species $C$. xanthocarpa, E. pyriformis, and $P$. peruviana, which presented similar results for the transversal and tangential sections. The region next to the bark of $M$. retorta presented approximately $17 \%$ larger results for the radial section when compared to the transversal section. Finally, the intermediate position of P. peruviana was similar for all three anatomical sections.

Regarding the parameter $\mathrm{L}^{*}$ for the factor region of the disc, species C. xanthocarpa, M. retorta, and P. peruviana presented decreasing results on the direction bark-pith. According to Delucis et al. (2014), this behavior is explained by the fact that the value of $\mathrm{L}^{*}$ is higher in the sapwood region, where we observe lower

FLORESTA, Curitiba, PR, v. 49, n. 2, p. 353-362, abr/jun 2019.

Vieira. H. C. et.al.

ISSN eletrônico 1982-4688

DOI: $10.5380 /$ rf.v49 i2.58236 
concentrations of lignin and extractive deposits. Only the measurements made in the tangential section of $P$. peruviana differed from this tendency, since we did not observe statistical differences between the regions of the disc. The wood of the remaining species (E. pyriformis) was not influenced by the region of the disc in the transversal and radial sections. However, in the tangential section, the results were superior on the regions next to the pith and intermediate.

Regarding the parameter $\mathrm{a}^{*}$, the species did not present a general pattern. Silva et al. (2015) also observed this tendency when describing the colorimetry of wood of eight native species of the state of Rio Grande do Sul, in the Southern Brazil. In relation to the factor anatomical section, E. pyriformis did not present any difference among the samples. We also observed this aspect in $C$. xanthocarpa in the regions next to the bark, and in $P$. peruviana in the regions next to the bark and next to the pith. The lowest results tended to be presented in the transversal section in the samples of $C$. xanthocarpa, in the regions next to the pith and intermediate, in all samples of $M$. retorta, and in the intermediate region of $P$. peruviana. Atayde et al. (2011) also observed it when characterizing the colorimetric parameters of the three sections of the wood of muirapiranga. As far as the regions of the disc are concerned, C. xanthocarpa and P. peruviana showed no significant statistical difference, such as the radial section of E. pyriformis. Regarding the transversal and tangential sections of the latter species, the sample next to the bark showed an increase of respectively $32 \%$ and $40 \%$. We noticed the reverse behavior for the position next to the bark of $M$. retorta, with a reduction of $26 \%$ in the transversal, $12 \%$ in the tangential, and $46.8 \%$ in the radial section.

As for the parameter $b^{*}$, the values tended to be smaller for the transversal section and equal for the radial and tangential sections. Autran and Gonçalez (2006) also observed similar values for these sections when assessing rubber trees. Only three samples deviated from this tendency: samples of the positions next to the pith and next to the bark of E. pyriformis, in which all values were statistically the same; and the sample of the position next to the bark of $C$. xanthocarpa, in which the transversal and tangential sections had the lowest values. Regarding the region of the disc, the radial and tangential sections of species C. xanthocarpa, M. retorta, and $P$. peruviana did not present significant differences among the regions next to the bark, intermediate and next to the pith. In the species E. pyriformis, the value of the parameter b* increased in the position next to the bark, as well as in the transversal section of the other species. Csordós et al. (2014) also detected this facet on varieties of Robinia.

For the parameter $\mathrm{C}$, when considering the anatomical sections, all species had similar values for the tangential and radial sections in the majority of the samples, while the transversal section presented the lowest results. According to Nishino et al. (1998), this phenomenon can be explained by the anatomical characteristics of the wood, mainly by the orientation of the rays. Only two samples were dissimilar to this pattern: sample of the region next to the bark of $C$. xanthocarpa, with similar values in the transversal and tangential sections and superior values in the radial section; and samples next to the bark and next to the pith of E. pyriformis, with equal values in all sections. Considering the different regions of the disc, the values obtained for P. peruviana were the same in all sections. Regarding E. pyriformis, we noted higher values in the position next to the bark, in all sections. As for $C$. xanthocarpa, the transversal section presented higher values for the region next to the bark. Regarding $M$. retorta, the radial plane had the highest result in the region next to the pith. For the other sections of these species, the values were similar among the different regions of the disc.

For the parameter h*, C. xanthocarpa did not present variations among the regions of the disc and anatomical sections, and $P$. peruviana presented similar results for the different regions of the disc, in all the anatomical sections; in the other species, the lowest values tended to be found in the transversal section. Exceptions to this tendency were the position next to the bark of E. pyriformis, with similar results for all sections; and the position next to the bark of $M$. retorta, with higher values for the radial section and similar values among the others. As for the anatomical section, E. pyriformis presented similar results for all regions of the disc evaluated. In $M$. retorta and $P$. peruviana, there was a tendency to decrease the values in the direction bark-pith.

\section{Principal Component Analysis (PCA)}

In the analysis of the PCA using the original spectra, the separation between E. pyriformis and the other species analyzed was evident (Figure $2 \mathrm{~A}$ ). In order to improve the visualization of the results, the mean data of all samples measured were analyzed in the plot of Figure $2 \mathrm{~B}$, which evinces even more the separation of E. pyriformis. We made two plots based on the means of the spectra for the transversal (Figure 2C) and longitudinal (Figure 2D) sections to verify possible distinctions among the remaining species after the removal of the outliers. Moreover, we performed the graphical analysis for both sections jointly, as there was no difference between the radial and tangential sections in the majority of the results (as we had previously analyzed). Nonetheless, all the plots generated using the original spectra of samples presented similar results, and only the species E. pyriformis was distinguished by not being grouped with the other species. Analyzing the 
PCA, we verified high significance level of PC $1(98 \%-99 \%)$ and high influence of the wavelength range between 570 and $620 \mathrm{~nm}$.

The same previous pattern was used for the PCA of the parameters $\mathrm{L}^{*}, \mathrm{a}^{*}$ and $\mathrm{b}^{*}$, whose data are represented in Figure 2E. Subsequently, we generated Figure 2F by removing the outliers, based on the means of all data; Figure $2 \mathrm{G}$, based on the mean data of the transversal section; and Figure $2 \mathrm{H}$, based on the mean data of the longitudinal (radial and tangential) section. We ascertained then that the samples presented the same behavior of the plots generated with the original spectra, in which E. pyriformis deviated from the others. Considering the mean of all sections, in addition to the deviation of E. pyriformis, we observed a slight relation of the results for $P$. peruviana, which therefore remained grouped with $C$. xanthocarpa and $M$. retorta. The significance values of PC1 were $99 \%$ for all plots of PCA generated with the parameters L*, $a^{*}$ and $b^{*}$. The parameter that showed the greatest influence on the results was L*.

\section{Original Spectra Analysis}

We observe that E. pyriformis had the highest reflectance values in Figure 3. This result suggests that this species differs from the others because it is clearer, ergo confirming the high results previously observed for b*. C. xanthocarpa, $M$. retorta and $P$. peruviana displayed similar reflectance curves, mainly approaching violet $(360-440 \mathrm{~nm})$ and red $(625-740 \mathrm{~nm})$ wavelengths. However, in the range of $500-625 \mathrm{~nm}$ (predominantly yellow), there is a slight separation between the curves. Therefore, it is possible to infer that this range has the greatest potential to differentiate these species, corroborating the results obtained in the PCA, in which we confirmed greater influence on the results in the interval 570 - $620 \mathrm{~nm}$ (yellow color).

In addition, it is possible to correlate the information obtained by the original spectra with the parameters $\mathrm{L}^{*}, \mathrm{a}^{*}$ and $\mathrm{b}^{*}$. E. pyriformis, which is classified as having high brightness, is also the clearest. Another relevant factor is the species differentiation, even considering the proximity between the reflectance curves, according to the classification of Camargos and Gonçalez (2001). It proves that the use of information on the reflectance curve and colorimetric parameters $\mathrm{L}^{*}, \mathrm{a}^{*}$ and $\mathrm{b}^{*}$ may be more efficient for species differentiation.

\section{CONCLUSIONS}

- There were significant differences among the colorimetric parameters for the wood of the four species of Myrtaceae analyzed. Moreover, it is possible to affirm that parameter $b^{*}$ is the most influenced parameter by the difference among the species.

- The factors region of the disc and anatomical section presented specific influences for each species. However, we noticed the tendency of chromatic $b^{*}$ to be smaller in the transversal section.

- For PCA, based on the original spectrum and values of $\mathrm{L}^{*}, \mathrm{a}^{*}$ and $\mathrm{b}^{*}$, only the wood of E. pyriformis differed from the other species.

- Visible spectroscopy revealed potential for differentiation of species.

\section{ACKNOWLEDGEMENT}

The authors thank the Santa Catarina State University (UDESC) for the study material, the Federal University of Paraná (UFPR) for the physical structure, the Academic Publishing Advisory Center (Centro de Assessoria de Publicação Acadêmica, CAPA) of the Federal University of Paraná for assistance with English language editing, and the Coordination for the Improvement of Higher Education Personnel (CAPES) for financial support.

\section{REFERENCES}

ATAYDE, C.M.; GONÇALEZ, J.C.; CAMARGOS, J.A.A. Características colorimétricas entre as seções anatômicas da madeira de muirapiranga (Brosimum sp.). Cerne, v.17, n.2. p.231-235, 2011.

AUTRAN, C. S.; GONÇALEZ, J. C. Caracterização colorimétrica das madeiras de muirapiranga (Brosimum rubescens Taub.) e de seringueira (Hevea brasiliensis), clone TJIR 16 Müll Arg. visando à utilização em interiores. Ciência Florestal, v. 16, n. 4, 2006.

BARROS, S. V. S.; MUNIZ, G. I. B.; MATOS, J. L. M. Caracterização colorimétrica das madeiras de três espécies florestais da Amazônia. Cerne, v. 20, n. 3, 2014.

BUCHELT, B.; WAGENFÜHR, A. Evaluation of colour differences on wood surfaces. European Journal of Wood and Wood Products, v. 70, n. 1-3, p. 389-391, 2012. 
CADEMARTORI, P. H. G.; SCHNEID, E.; GATTO, D.A.; STANGERLIN, D.M.; BELTRAME, R. Thermal modification of Eucalyptus grandis wood: variation of colorimetric parameters. Maderas. Ciencia $\mathbf{y}$ Tecnología, v. 15, n. 1, p. 57-64, 2013.

CAMARGOS, J. A. A.; GONÇALEZ, J. C. A. A colorimetria aplicada como instrumento na elaboração de uma tabela de cores de madeira. Brasil Florestal, v. 71, p.30-41, 2001.

CSORDÓS, D.; NÉMETH R.; BAK, M. Variation of colour properties between and within new Robinia varieties with enhanced growing rates from different sites. BioResources, v. 9, n. 4, p. 7099-7108, 2014.

DELUCIS, R. D. A.; TABORDA, V. C.; CORREA, L. W.; VEJA, R. D. A.; GATTO, D. A. Avaliação da cor dos lenhos juvenil e adulto de cedro por meio do método CIE L* $\mathrm{a}^{*} \mathrm{~b}^{*}$. Tecnologia em Metalurgia, Materiais e Mineração, v. 11, n. 3, p. 251, 2014.

FERREIRA, D. F. SISVAR: um programa para análises e ensino de estatística. In: Revista Symposium. 2008. p. 36-41.

GARCIA, R. A.; MARINONIO, G. B. Variação da Cor da Madeira de Teca em Função da Densidade e do Teor de Extrativos. Floresta e Ambiente. v. 23, n.1 p.124 - 134. 2016.

GARCIA, R.A.; OLIVEIRA, N.S.; NASCIMENTO, A.M.; SOUZA, N.D. Colorimetria de madeiras dos gêneros Eucalyptus e Corymbia e sua correlação com a densidade. Cerne, v.20, n.4, p.509-517, 2014.

GASPER, A. L.; SEVEGNANI, L.; VIBRANS, A. C.; MARCOS SOBRAL, M.; UHLMANN, A.; LINGNER, D. V.; RIGON JÚNIOR, M. J.; VERDI, M.; SANTOS, A. S.; DREVECK S.; KORTE, A. Inventário florístico florestal de Santa Catarina: espécies da Floresta Ombrófila Mista. Rodriguésia, v. 64, n. 2, p. 201-210, 2013.

MMA, Lista Nacional Oficial de Espécies da Flora Ameaçadas de Extinção. Ministério do Meio Ambiente. Portaria MMA nº 443, 2014.

MORI, C. L. S. O.; LIMA, J. T.; MORI, F. A.; TRUGILHO, P. F.; GONCALEZ, J. C. Caracterização da cor da madeira de clones de híbridos de Eucalyptus spp. Cerne, v. 11, n. 2, p. 137-146, 2005.

MORI, C.L.S.O.; MORI, F.A.; LIMA, J.T.; TRUGILHO, P.F.; OLIVEIRA, A.C. Influência das características tecnológicas na cor da madeira de eucaliptos. Ciência Florestal, v. 14, n. 2, p. 123-132, 2004.

NISGOSKI, S.; DE MUNIZ, G.I.B.; GONÇALVES, T.A.P.; BALLARIN, A.W. Use of visible and near-infrared spectroscopy for discrimination of eucalypt species by examination of solid samples. Journal of Tropical Forest Science.v.29, n.3, p.371-379, 2017.

NISHINO, Y.; JANIN, G.; CHANSON, B.; DÉTIENNE, P.; GRIL, J.; THIBAUT, B. Colorimetry of wood specimens from French Guiana. Journal of Wood Science, v. 44, n. 1, p. 3-8, 1998.

NISHINO, Y.; JANIN, G.; YAINADA, Y.; KITANO, D. Relations between the colorimetric values and densities of sapwood. Journal of Wood Science, v. 46, n. 4, p. 267-272, 2000.

NUNES, J. D.; TORRES, G. A.; DAVIDE, L. C.; CAMPOS, J. M. S. Bandeamento cromossômico e conteúdo de DNA em espécies tropicais de Pinus. Scientia Forestalis, v. 37, p. 213-218, 2009.

OLIVEIRA, A. A.; SIQUEIRA, P. H.; NISGOSKI, S.; MUNIZ, G. B. D.; FERREIRA, J. H. Identificação de madeiras utilizando a espectrometria no infravermelho próximo e redes neurais artificiais. TEMA (São Carlos), v. 16, n. 2, p. 81-95, 2015.

ROSU, D.; TEACA, C. A.; BODIRLAU, R.; ROSU, L. FTIR and color change of the modified wood as a result of artificial light irradiation. Journal of Photochemistry and Photobiology B: Biology, v. 99, n. 3, p. 144-149, 2010 .

SILVA, E. S.; STANGERLIN, D. M.; GATTO, D. A.; CALEGARI, L.; PARIZ, E. Colorimetria da madeira de oito espécies nativas do estado do Rio Grande do Sul, Brasil. Revista Ciência da Madeira, v. 6, n. 1, p. 31-37, 2015.

Silva, R. A. F.; SETTER, C.; MAZETTE, S. S.; DE MELO, R. R.; STANGERLIN, D. M. Colorimetria da madeira de trinta espécies tropicais. Revista Ciência da Madeira. v. 8, n. 1, p. 36-41, 2017.

SOUZA, V.C.; LORENZI, H. Botânica Sistemática: Guia ilustrado para identificação das famílias de Angiospermas da flora brasileira, baseado em APG II. $2^{\text {a }}$ E.d. Nova Odessa, Instituto Plantarum, 2008. 704p.

VANCLAY, J.K.; HENSON, M.; PALMER, G. Color variation and correlations in Eucalyptus dunnii sawnwood. Journal of Wood Science, v. 54, n. 6, p. 431-435, 2008. 